\title{
The Combination of US Economy Policies under the Liquidity Trap Crisis
}

\author{
Ganyin Cai \\ School of Economics, University of Nottingham Ningbo, China \\ hmxgc1@nottingham.edu.cn
}

\begin{abstract}
This paper examines what policy combinations the US economy should adopt to escape a possible liquidity trap under the impact of the COVID-19. We used the method of argumentation and drew on the previous related theories for comprehensive analysis, including fiscal policy, unconventional open market operations, expectations management and multinational policy coordination, to produce policy recommendations.
\end{abstract}

Keywords: Liquidity Trap; Fiscal Policy; Expectation Management; Policy Coordination.

\section{Introduction}

The COVID-19 epidemic that swept the world in 2020 had a severe impact on the global economy. Countries generally cut nominal interest rates to stimulate the economy. However, as the recession dragged on and nominal interest rates approached zero lower bound, the room for maneuver of monetary policy in each country gradually diminished. The liquidity trap has become a major problem for central banks around the world, and the US is no exception. As the world's largest economy, a recovery in the US while escaping a liquidity trap will be important for global economic growth.

This paper first introduces the definition and causes of liquidity trap, including Hicks' 1937 IS-LM supply and demand aggregate analysis framework and Krugman's intertemporal model based on micro basis. We will then introduce the US economy under the impact of the COVID-19 in 2020. Finally, from the perspectives of fiscal policy, unconventional open-market operations, expectation management and multinational policy coordination, this paper analyzes how the United States can escape from the liquidity trap caused by the impact of the COVID-19 in 2020, and gives policy suggestions.

\section{Liquidity Trap}

\subsection{The Definition of the Liquidity Trap}

Firstly, let's discuss what a liquidity trap is. Keynes (1936) proposed in the money demand theory that when the interest rate drops to the lowest level, the elasticity of money demand tends to be infinite, and further lowering the interest rate cannot stimulate the economy, thus falling into the liquidity trap. Under the framework of IS-LM, Hicks (1937) put forward the hypothesis that there is an interest rate floor in the left part of LM (as shown in Figure 1). Krugman (2000) defines liquidity trap as follows -- as a situation in which even a zero-interest rate is insufficiently low to produce full employment. Although the definition is slightly different, the essence is the failure of traditional monetary policy for economic regulation when the nominal interest rate is close to zero lower bound.

\subsection{The Impact of the Liquidity Trap}

Specifically, under the IS-LM framework, the short-term equilibrium of the economy is jointly determined by the upward-sloping LM curve and the downward-sloping IS curve. When the economy is overheated and prices rise, the bubbles can be suppressed by raising interest rates and reducing investment and consumption. However, when the economy is in depression, continuous price decline requires continuous reduction of nominal interest rate to stimulate the economy. When the nominal interest rate is close to zero, it cannot be further lowered, and the economic recession continues. In addition, when the nominal interest rate is zero, bonds and cash are completely substituted, and the 
traditional open market operation of buying and selling bonds does not change anything, and then monetary policy becomes ineffective. In Krugman's intertemporal model based on micro basis (see appendix for the formula), when the implied nominal interest rate is negative, the cash-in-advance constraint is no longer binding, some cash acts as a store of value like bonds, and any additional money supply cannot stimulate the economy, that is, monetary policy is ineffective.

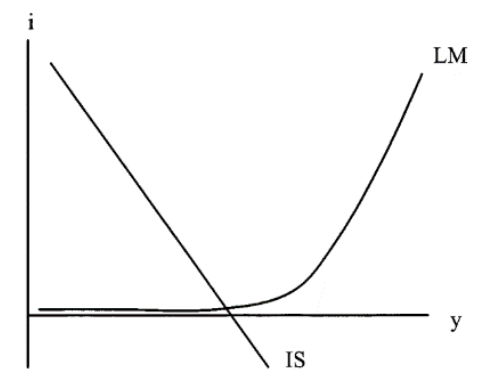

Figure 1. Liquidity trap in IS -LM framework

\section{The U.S. Economy}

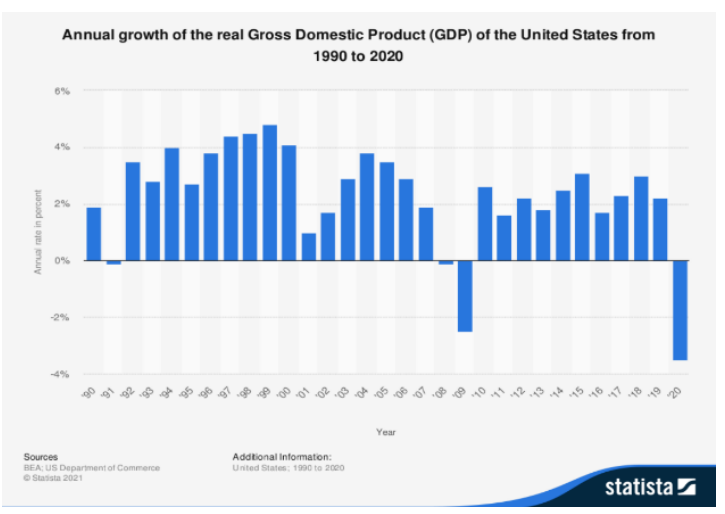

Figure 2. U.S. GDP growth over the last 30 years

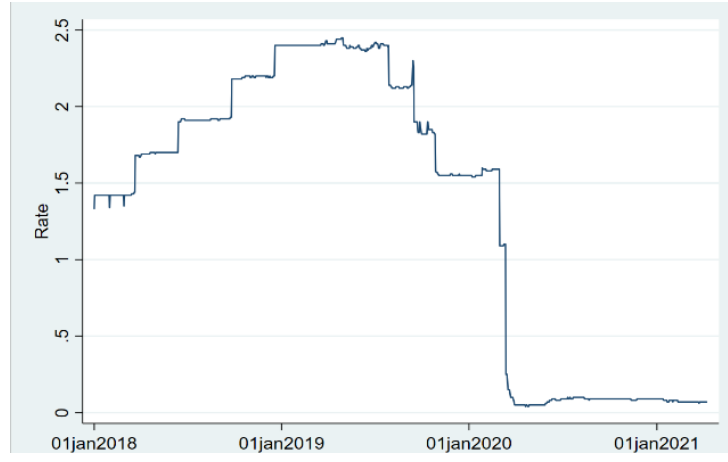

Figure 3. Federal interest rate chart

Having concluded the theoretical section above, we turn to the state of the US economy. Due to the impact of COVID-19, economic production stagnated, people's panic about the uncertain future led to the increase of savings and the decline of private sector consumption, both sides of the economic supply and demand were greatly affected. America's GDP growth will fall to $-3.5 \%$ in 2020 , the first negative growth in nearly a decade (figure 2). In the face of the economic recession, the Federal Reserve, as the central bank of the United States, adopted an extremely loose monetary policy and significantly reduced the federal funds rate from 1.59\% on March 3, 2020 to $0.05 \%$ on April 2, 2020. So far (April 2021) it has remained at $0.07 \%$ (figure 3). During the year, nominal interest rates remained close to zero lower bound for a long time, with little room for further reductions, and the economic shock from the epidemic was far from over, leaving the United States on the verge of falling 
into a liquidity trap. In order to avoid Japanese-style stagflation and liquidity trap and the emergence of "lost two decades", we draw on previous theories to analyze what kind of policies or policy combinations are needed to prevent the United States from falling into the liquidity trap while the impact of the epidemic is not over yet and the economic recovery of the United States is ensured.

\section{Policy Options}

\subsection{Fiscal Policy}

Let's start with fiscal policy, which consists primarily of increased government spending $(\mathrm{G})$ and lower tax rates (T). Under the traditional IS-LM framework, expansionary fiscal policy makes the IS curve shift to the right. When the LM curve remains unchanged, the equilibrium point represented by the intersection of the two curves (when the goods market and the money market reach equilibrium at the same time) moves to the right, and economic output $Y$ rises. To be specific, tax reduction can increase residents' current disposable income, and both private consumption and private investment will increase with the rise of income level, thus increasing economic output. The increase of government expenditure can increase the total amount of social investment and consumption, and get the economic output higher than the expenditure through the multiplier effect. The United States began with the passage of the "Coronavirus Preparedness and Response Supplementary Appropriations Act" on March 6, 2020, which added \$8.3 billion to U.S. public health spending, followed by the passage of a series of fiscal expansion bills. Tax cuts and subsidies, among other things, have boosted Americans' disposable income considerably, including $\$ 250$ billion in additional unemployment benefits ( $\$ 600$ a week), $\$ 290$ billion in personal aid (A one-time grant of $\$ 1,200$ ) and Pay protection plan (PPP), which Played a crucial role in boosting private sector consumption and private investment. In addition, U.S. government spending on health care and the infrastructure investment have all raised the total amount of social investment. And compared to normal times, fiscal policy has a large multiplier effect when the nominal interest rate is near its zero lower bound, argued by Yepez (2018). This means that fiscal expansion in the US now has a more significant stimulus effect than in normal time. When the COVID-19 hit the US economy, the nominal interest rate was close to zero lower bound and the traditional monetary policy was limited, the US implemented a series of fiscal expansion policies, which could not only restore economic output, but also make the US escape from the liquidity trap.

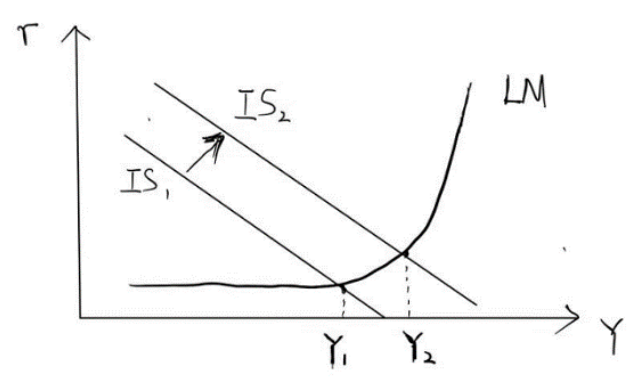

Figure 4. Fiscal policy in the IS-LM framework

But there are problems with fiscal policy. The first is the unsustainability of long-term fiscal expansion caused by government budget constraints. The United States has been running budget deficits for a long time since 2002 (Figure 5, 2020 and beyond are projected). In 2009, the budget deficit hit $\$ 1.41$ trillion as a result of the financial crisis. Due to COVID-19, the government deficit reached \$3.13 trillion in fiscal year 2020 (source: US Treasury, 2020). The long-term accumulated budget deficit will not only affect the sustainability of the government's future policies, but also make the public question the solvency of the government in the future, thus affecting the public confidence, which is detrimental to the sustained economic recovery. Secondly, due to the existence of Ricardian Equivalence, when consumers have rational expectation, the increase in disposable income brought 
about by the reduction of current tax rate will not stimulate consumers to increase consumption in the current period, because these consumers with rational expectation believe that the tax rate will return to the normal level in the future. It may even be due to higher-than-normal taxes in the future to reduce the budget deficit. Such "Ricardian consumers" would therefore save more when tax rates fell in the current period, and the stimulative effect of fiscal expansion would be less. Given these constraints, fiscal expansion can be used as a policy option to pull the US economy away from the liquidity trap in the short term rather than the long term.

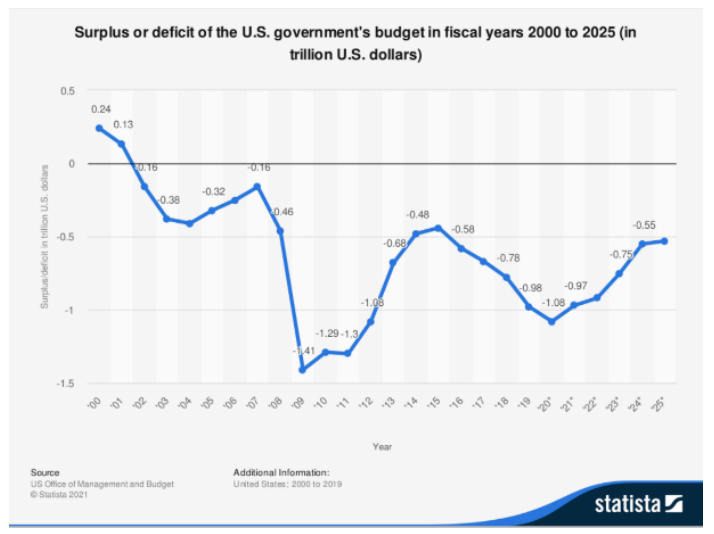

Figure 5. Recent U.S. government budgets (statistics or projections)

\subsection{Unconventional Open Market Operations}

Secondly, we consider unconventional open market operations, including purchases of foreign currency assets and domestic long-term bonds. Krugman (2000) believes that because foreign bonds and domestic long-term bonds do not completely substitute short-term bonds, the government keeps buying long-term bonds, which makes bond prices rising and long-term interest rates fall, and private investors convert part of their savings from bonds to other short-term assets. Foreign currency assets such as foreign bonds are purchased in the foreign exchange market for capital output. Both of them can close the ex- ante gap between NX and S-I (Figure 6), thus stimulating the economy. It is worth noting that due to the unique status of the US dollar as the global reserve currency, the US government can constantly export US dollar capital to exchange for foreign currency assets, to escape from the liquidity trap and transfer economic pressure to other countries at the same time. Therefore, the purchase of foreign currency assets is theoretically particularly effective for the US to get out of the liquidity trap. However, due to the constraints of the Fed's balance sheet, it cannot buy long-term Treasury bonds without restraint. In addition, because of its confidence in the dollar as the international reserve currency, the U.S. government cannot indefinitely create and export dollars to buy foreign currency assets. Thus, unconventional open market operations can only be used as part of short-term US policy to escape the liquidity trap.

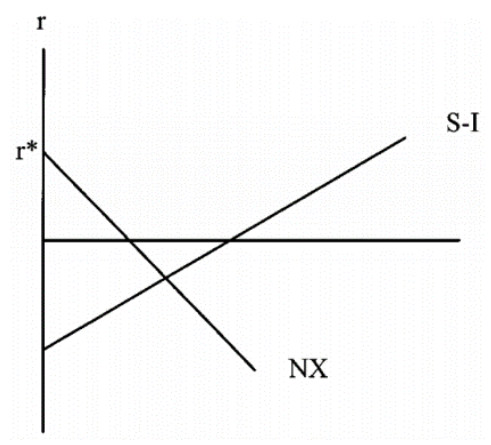

Figure 6. ex- ante gap between NX and S-I 


\subsection{Expectation Management}

Then we consider expectations management, such as inflation targeting. Eggertsson and Woodford (2004) pointed out that according to Fisher equation,

$$
i_{t}=r_{t}+E_{t} \pi_{t+1}
$$

A credible commitment by the central bank to raise the future money supply and the expected inflation rate in the public market can reduce the current real interest rate when the nominal interest rate is close to zero in the liquidity trap, and stimulate the private sector to convert savings into consumption in the current period, thus achieving economic expansion. When the nominal interest rate is kept close to zero for a long time, the opportunity cost of current consumption can be reduced and current private sector consumption can be increased through the influence of the determinant of long-term interest rate. In addition, the long-term economic stimulus promised and implemented by the government creates the expectation of future economic expansion in the private sector, and through the channels of the permanent income hypothesis, households tend to smooth consumption and increase current consumption. All three of these expectation-managed channels can achieve economic expansion. Among them, the relationship between current economic output, current inflation and current policy interest rate is described as follows under the framework of New Keynesian model, including the new Keynesian Phillips curve, the new Keynesian IS curve and the Taylor rule as the policy rate to close this model.

$$
\begin{gathered}
\pi_{t}=\beta \pi_{t+1}+k X_{t}+\epsilon_{t} \\
X_{t}=E_{t} X_{t+1}-\left(\frac{1}{\sigma}\right)\left(i_{t}-E_{t} \pi_{t+1}-r\right)+u_{t} \\
i_{t}=r+\delta_{\pi} \pi_{t}+\delta_{X} X_{t}+v_{t}
\end{gathered}
$$

Future inflation expectations affect not only current inflation but also current economic output. Accordingly, the Federal Reserve should continuously release the signal of easy money and achieve part of its goals as agreed. While making a long-term commitment of nominal interest rate close to zero, the Federal Reserve can generate individuals' expectations of future sustained inflation, and promote the consumption of private sectors in the current period through the above channels, to realize the so-called "mouth pulling economy".

As forward guidance requires government credibility, relatively low cost and sustainability, which is in line with the reality of the United States, it can be used as one of the current policies to get rid of the liquidity trap and restore the economy.

It is worth noting that the current new view, "Neo-Fisherism" assumes that inflation is hard to pull up in the short run near zero lower bound. In the long - term monetary neutrality advocates to raise interest rates to boost inflation. But such a policy would be detrimental and risky to the short-term recovery. Considering the political needs and policy inconsistency of the US administration change, we do not use the interest-rate increase to drive inflation advocated by the new Fisher doctrine as a response.

\subsection{Multinational Policy Coordination}

Finally, we emphasize policy coordination between different economies. Due to the economic recession caused by the global outbreak of COVID-19, governments around the world generally adopted interest rate cuts to stimulate the economy. The federal funds rate in the United States is close to zero, while the deposit rate in Europe will remain at $-0.5 \%$ until April 2021. In Japan, the nominal interest rate will remain negative for a long time. All major economies in the world have the tendency to fall into the liquidity trap. David and Michael (2013) pointed out that in a multi-country setting, 
monetary policy may not be ineffective in response to a liquidity trap shock. Therefore, the Federal Reserve should strengthen communication with the central banks of major economies (Europe, Japan), coordinate policies together, and reasonably handle the spillover effects of monetary policies, which will be beneficial to the economic recovery of the United States and escape from the liquidity trap.

\section{Conclusion}

The federal funds rate was close to zero lower bound in the face of an economic recession caused by the impact of COVID-19. Based on the above analysis, it is suggested that the US fiscal and monetary authorities continue to use the expansionary fiscal policy of tax cuts and increased government spending in the short term, and at the same time adopt unconventional open market operations such as purchasing foreign currency assets and domestic long-term government bonds, and carry out expectation management to set inflation target in the long term. In addition, the Fed should strengthen its communication with other major central banks and conduct policy coordination. Using a combination of these policies, the United States can escape from the liquidity trap and achieve economic recovery.

\section{References}

[1] J. R. Hicks, 1937. Mr. Keynes and the "Classics"; A Suggested Interpretation. Econometrical, 5(2), pp. 147-159.

[2] Krugman, Paul, 2000. Thinking About the Liquidity Trap. Journal of the Japanese and international economies, 14(4), pp.221-237.

[3] Yépez, Carlos A, 2018. The impact of credit and fiscal policy under a liquidity trap. The North American journal of economics and finance, 44, pp.1-11.

[4] Eggertsson G.B \& Woodford M, 2004. Policy Options in a Liquidity Trap. The American economic review, 94(2), pp.76-79.

[5] David Cook \& Michael B. Devereux, 2013. Sharing the Burden: Monetary and Fiscal Responses to a World Liquidity Trap. American economic journal. Macroeconomics, 5(3), pp.190-228.

[6] Keynes, J.M., 1936. The general theory of employment, interest and money, London: Macmillan, St. Martin's Press.

\section{Appendix}

Krugman's intertemporal model:

$$
U=\left(\frac{1}{\rho}\right) \sum_{t} D^{t} c_{t}^{\rho}
$$

Utility function

$$
P_{t} c_{t} \leq M_{t}
$$

Cash -in-advance constraint each period

$$
\left(1+i_{t}\right)\left(\frac{P_{t}}{P_{t+1}}\right)=\left(\frac{1}{D}\right)\left(\frac{c_{t+1}}{c_{t}}\right)^{-\rho}
$$

Euler condition on consumption, nominal interest rate and price. 